\title{
Restriction fragment length polymorphism in the exon 2 of the BoLA-DRB3 gene in Chinese Holstein of the south China
}

\author{
Xiu-Xiang Wu, Zhang-Ping Yang ", Xiao-Long Wang, Yong-Jiang Mao, Shu-Chun Li, Xue-Kui Shi, \\ Ying Chen
}

Key Lab of Animal Genetics, Breeding \& Molecular Design, College of Animal Science and Technology Yang Zhou University, Yang Zhou, Jangsu, China.

Email: ${ }^{*}$ zhangpy65@vip.sohu.com

Received 30 September 2008; revised 28 November 2009; accepted 30 December 2009.

\begin{abstract}
The genetic diversity of the exon2 of BoLA-DRB3 (BoLA-DRB3.2) in Chinese Holstein cattle of the south China was investigated by hemi-nested polymerase chain reaction-restriction fragment length polymorphism (PCR-RFLP) technique. Six, four and eleven RFLP patterns were found after digestion with the restriction enzymes Hae III, Bst YI and Rsa I, respectively. The DNA sequence showed and twentyfive DRB3.2 alleles. GLM model analysis indicated that lactation and calving season have positive correlation with SCC (Somatic Cell Count) $(\mathbf{p}<0.01)$, BoLA-DRB3.2*3, *8, *18 and $* 26$ were associated with lower SCC $(p<0.01)$. The present findings concluded that mastitis is a severe hinder of milk production and technology. Therefore, future re-searches should focus on associations of mastitis with BoLA haplotypes rather than single BoLA genes
\end{abstract}

Keywords: PCR-RFLP; BoLA-DRB3.2; Chinese Holstein; Genetic Polymorphism; SCC

\section{INTRODUCTION}

Major Histocompatibility Complex (MHC), also called Bovine Lymphocyte Antigen (BoLA) has received wide attention because of their association with host immunity. The BoLA gene is located on the short arm of bovine chromosome 23 (BTA23) and consists of three class, I, II and III [1].The class II gene are distributed in two regions, II a and II $\mathrm{b}$, with an approximate recombination frequency of $17 \%$ [2]. The DRA, DRB, DQA, and DQB genes are located in the II a region, while the DOB, DYA, DYB and DIB genes in the IIb region. There are at least three DRB-like genes (DRB1, DRB2 and DBR3) in the BoLA region, among which only the DRB3 gene is expressed considerably and is highly polymorphic [1].

A polymerase chain reaction-restriction fragment length polymorphism (PCR-RFLP) technique developed by Van Eijk et al. [3] determined alleles in the second exon of BoLA-DRB3 gene (BoL-DRB3.2). This method has advantage of using small amounts of genomic DNA and being adaptable to crude DNA preparations. This advantage will be magnified in case where the studied population is relatively large and the process of extracting DNA with conventional phenol-chloroform methods becomes tedious and labor-intensive. Therefore, PCRRFLP is a rapid and useful method for DRB3.2 typing in cattle families. But for the outbreed populations sequencing and hybridization techniques are required.

Recently, many researches on BoLA-DRB3 have been reported $[4,5,6,7]$.This study describes genetic variability in the BoLA-DRB3 and its relationship with SCC and production performance in Chinese Holstein cow. This is the first study of the DNA polymorphism of the BoLA-DRB3 gene in Chinese Holstein cows of the south China.

\section{MATERIALS AND METHODS}

\subsection{Animals and DNA Extraction}

Chinese Holstein $(n=629)$ from Shanghai Brightlight Dairy Company were used in the current study. Approximately $5 \mathrm{~mL}$ of blood was collected from each animal via the caudal rein. The blood was anticoagulated with anticoagulant citrate dextrose (ACD) and stored at -20C.Genomic DNA was extracted from whole blood by the phenol-chloroform extraction method described by Sambrook with some modifications. The quality of the genomic DNA was checked by submarine Agarose gel electrophoresis, purity and concentration were check by spectrophotometer DNA samples with good quality, and purity and concentration were used for further analysis.

\subsection{PCR Amplification of BoLA-DRB3.2}

Exon 2 of BoLA-DRB3 gene (284bp) was amplified by semi-nest PCR, described by Miretti et al. [9], to im- 
prove the specificity of the PCR product. Primers HL-030 (5'-ATCCTCTCTCTGCAGCACATTTCC-3'), HL-031 (5'-TTTAAATTCGCGCTCACCTCGCCGCT-3') and HL-032 (5'-TCGCCGCTGCACAGTGAAACTCTC $\left.-3^{\prime}\right)$, described by Van Eijk [3], were used in the PCR reaction. Briefly, the first stage PCR was performed in a final volume of $20 \mu \mathrm{L}$ containing $50 \mathrm{ng}$ of template DNA, $0.5 \mathrm{pm}$ of primer HL-030 and HL-031, $2 \mu \mathrm{L}$ PCR buffer, $1.75 \mathrm{mM} \mathrm{MgCl} 2,0.25 \mathrm{mM}$ dNTPs, $1.5 \mathrm{U}$ Taq DNA Polymerase (Shanghai Sangon). This reaction system was predenatured at $94 \mathrm{C}$ for $4 \mathrm{~min}$ followed by 12 cycles of denaturizing $(94 \mathrm{C}$ for $1 \mathrm{~min})$, annealing $(60 \mathrm{C}$ for $1 \mathrm{~min})$ and elongation $(72 \mathrm{C}$ for $1 \mathrm{~min})$ and a final extension at $72 \mathrm{C}$ for $5 \mathrm{~min} .2 \mu \mathrm{L}$ of the first stage PCR product was used as template DNA.

For the second stage PCR in a final volume of $40 \mu \mathrm{L}$ containing $0.5 \mathrm{pM}$ of primer HL-030 and HL-032, $4 \mu \mathrm{L}$ PCR buffer $1.75 \mathrm{mM} \mathrm{MgCl} 2,0.25 \mathrm{mM}$ dNTPs, and $2 \mathrm{U}$ Taq DNA polymerase. The solution was predenatured at 94C for $4 \mathrm{~min}$ followed by 30 cycles of denaturizing (94C for $60 \mathrm{~s}$ ), annealing (63C for $45 \mathrm{~s}$ ), and elongation $(72 \mathrm{C}$ for $45 \mathrm{~s})$ and a final extension $(72 \mathrm{C}$ for $5 \mathrm{~min}) .5 \mu \mathrm{L}$ of the second stage PCR product was electrophoresed on $1.2 \%$ agarose gels to check the quality and specificity of DNA fragment amplification.

\subsection{RFLP}

To examine the nucleotide sequence variability at the BoLA-DRB3.2 locus, three end nucleotide restriction enzymes (Hae III, Bst YI and Rsa I) were chosen based on their cut site and ability to cut DNA in this exon. The second stage PCR products were digested with the restriction enzymes according to the manufacture's instructions. A $15 \mu \mathrm{L}$ of the second stage PCR product containing $8 \mu \mathrm{L}, 0.5 \mathrm{U}$ of restriction enzymes, and $6.8 \mu \mathrm{L}$ of $1 \times$ Buffer were digested at $37 \mathrm{C}$ for $12 \mathrm{~h}$ followed by inacting at $80 \mathrm{C}$ (Hae III and Bst YI) or $65 \mathrm{C}$ (RsaI) for $20 \mathrm{~min}$. The resulting DNA fragment were separated on $14 \%$ PAGE gels with $1 \times \mathrm{TBE}$ buffer $(0.9 \mathrm{M}$ Tris-Base, $0.09 \mathrm{M}$ Boric Acid, $2.5 \mathrm{mM}$ EDTA) at $150 \mathrm{~V}$ for $5 \mathrm{~h}$, using Msp I digested pBR322/MspI as a molecular marker. After ethidium bromide (EB) staining, the gels were photographed under UV light and the relative migrations of the DNA bonds were estimated. The restriction patterns obtained were compared with previously described restriction maps [10].

\subsection{DNA Sequencing}

BoLA-DRB3.2 DNA sequence was performed base on the restriction enzyme sites. The sequence was compared with the gene Bank sequences. http://www.projects.roslin.ac.uk/bola/bolanom.html

\subsection{SCC Analysis}

SCC is leukocytes that inter the milk from the alveoli and they are considered an important indicator of mastitis infection. The SCC of the experimental cows was detected every month. In order to express the effect of calving season on SCC, the data are divided into four parts according to calving season.

\subsection{Statistic Analyses}

GLM (General Linear Model) of SCC and production performance was performed by SAS6.12 (SAS Institute, 1996), the models are as follows:

$$
\mathrm{Yijkm}=\mu+\mathrm{Li}+\mathrm{Sj}+\sum \mathrm{blBoLAijkl}+\text { eijkm }
$$

Yijkm: SCC, Milk Yield, Fat Percent Protein percent $\mu$ : the average value, Li: lactation number, $\mathrm{i}=1 \sim 4, \mathrm{Sj}$ : calv-ing season $=1 \sim 4$, bl: regression coefficient of allele to SCC, $1=1 \sim 22$, BoLAijkl: the copy number of BoLA al-lele 1 in individual ijk, the value is 0,1 and 2, eijkm: random error.

\section{RESULTS}

\subsection{DRB 3.2 Amplification}

DNA bands of the expected size containing $267 \mathrm{bp}$ of exon 2, $3 \mathrm{bp}$ of the 3' intron and $14 \mathrm{bp}$ of the 5 'intron, were received by semi-nested PCR amplification (Figure 1). The specificity of the PCR product was very high, but some nonspecific bands were observed. Although these bands could not be eliminated by modifying PCR conditions, this did not affect the resolution of restriction patterns.

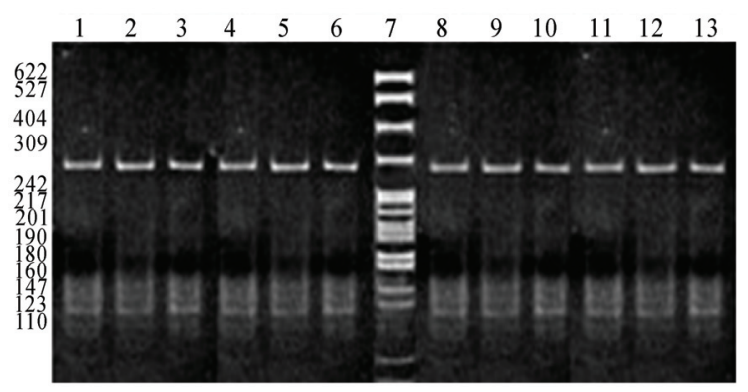

Figure 1. Patterns of the semi-nested PCR.

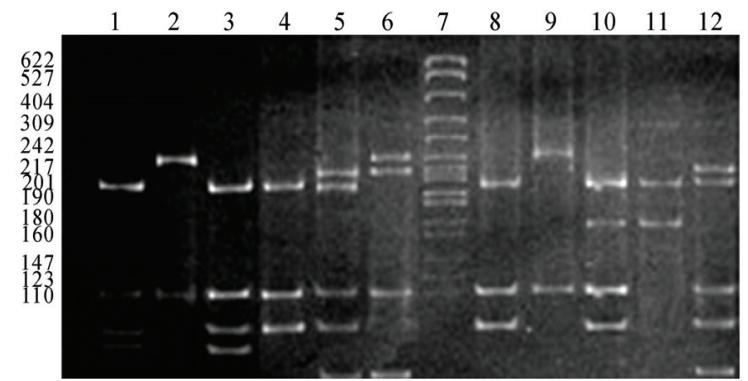

Figure 2. Genotypes of BoLA-DRB3.2 locus digested with Hae III. 


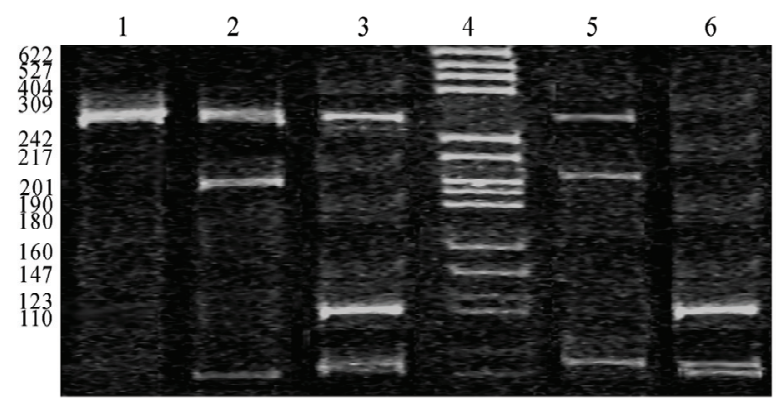

Figure 3. Genotypes of BoLA-DRB3.2 locus digested with Bst YI.

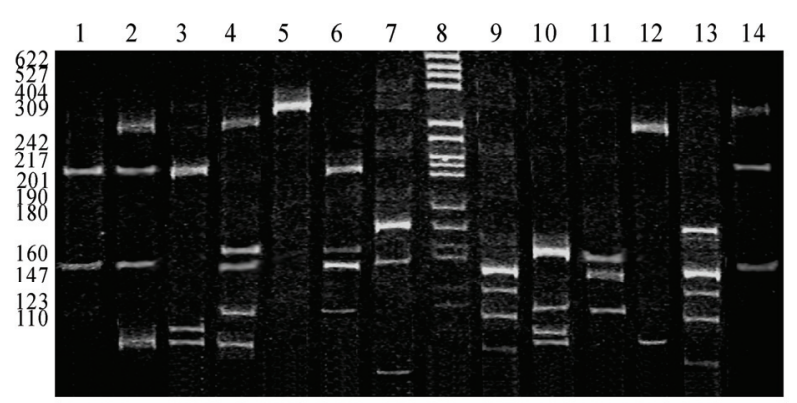

The DNA sequence was $284 \mathrm{bp}$, containing $267 \mathrm{bp}$ of exon 2, 3 bp of the 3 ' intron and $14 \mathrm{bp}$ of the 5 'intron.

\subsection{Identification of Restriction Patterns}

The 284 bp fragment of the BoLA-DRB3.2 gene in this study were digested with Rsa I, Hae III and Bst YI respectively. Six restriction patterns were identified with Hae III (See Table 1 and Figure 2). Bst YI resulted in four RFLP patterns a,b,d and e (See Table 1 and Figure $3)$. RsaI restriction patterns were so complex that eleven patterns were revealed in this study (See Table 2 and Figure 2).

\subsection{DNA Sequencing and Standard Naming}

Combining restriction patterns with Rsa I, Bst YI and Hae III in the whole sample, 22 DRB3.2 alleles found in the study were sequenced (See Table 2 and Table 3 ). Many mutants were indicated in the cut sites of restriction enzymes by DNA sequencing. The frequency of BoLA-DRB3.2 ranged from $0.003(2 * 34)$ to 0.220 $(2 * 22)$.

Figure 4. Genotypes of BoLA-DRB3.2 locus digested with Rsa I.

Table 1. Fragment Size and Frequencies of Restriction Patterns Digested with Enzymes.

\begin{tabular}{|c|c|c|c|c|c|c|c|}
\hline Enzyme & $\begin{array}{c}\text { Restriction } \\
\text { Patterns }\end{array}$ & $\begin{array}{l}\text { Fragment } \\
\text { Size(bp) }\end{array}$ & Frequency & Enzyme & $\begin{array}{c}\text { Restriction } \\
\text { Patterns }\end{array}$ & $\begin{array}{l}\text { Fragment } \\
\text { Size(bp) }\end{array}$ & Frequency \\
\hline Hae III & $\begin{array}{l}\mathrm{a} \\
\mathrm{b} \\
\mathrm{d} \\
\mathrm{e} \\
\mathrm{f} \\
\mathrm{h}\end{array}$ & $\begin{array}{l}167 / 65 / 52 \\
219 / 65 \\
190 / 65 / 29 \\
167 / 117 \\
167 / 65 / 48 / 4 \\
167 / 65 / 46 / 6\end{array}$ & $\begin{array}{l}0.598 \\
0.238 \\
0.049 \\
0.037 \\
0.061 \\
0.017\end{array}$ & Rsa I & $\begin{array}{l}\mathrm{b} \\
\mathrm{d} \\
\mathrm{f} \\
\mathrm{g} \\
\mathrm{h} \\
\mathrm{i}\end{array}$ & $\begin{array}{l}111 / 54 / 50 / 39 / 30 \\
143 / 111 / 30 \\
141 / 54 / 50 / 39 \\
141 / 104 / 39 \\
111 / 69 / 54 / 50 \\
180 / 54 / 50\end{array}$ & $\begin{array}{l}0.061 \\
0.024 \\
0.085 \\
0.082 \\
0.082 \\
0.006\end{array}$ \\
\hline Bst YI & $\begin{array}{l}a \\
b \\
d \\
e\end{array}$ & $\begin{array}{l}199 / 85 \\
284 \\
197 / 87 \\
112 / 87 / 85\end{array}$ & $\begin{array}{l}0.095 \\
0.823 \\
0.012 \\
0.070\end{array}$ & & $\begin{array}{l}1 \\
\mathrm{~m} \\
\mathrm{n}\end{array}$ & $\begin{array}{l}234 / 50 \\
111 / 104 / 69 \\
180 / 104 \\
284\end{array}$ & $\begin{array}{l}0.113 \\
0.241 \\
0.195 \\
0.058\end{array}$ \\
\hline
\end{tabular}

Table 2. Allele Frequencies of BoLA-DRB3.2 identified by PCR-RFLP analysis.

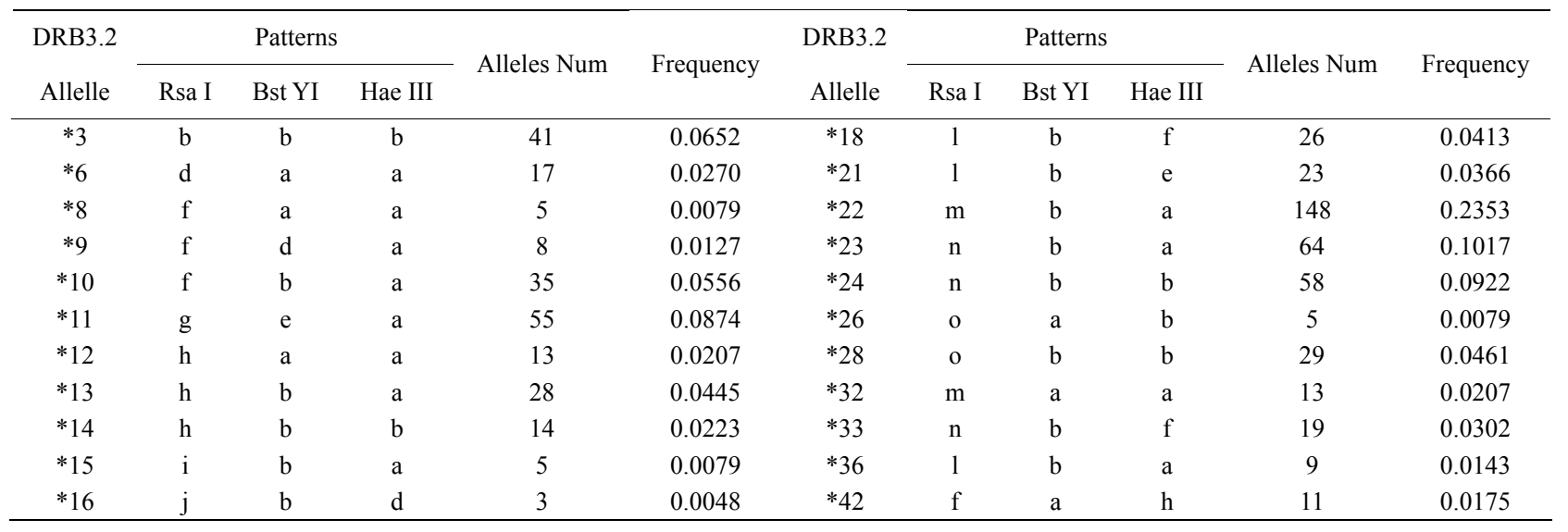


Table 3. The sequences of BoLA-DRB3.2 alleles indicated in the paper.
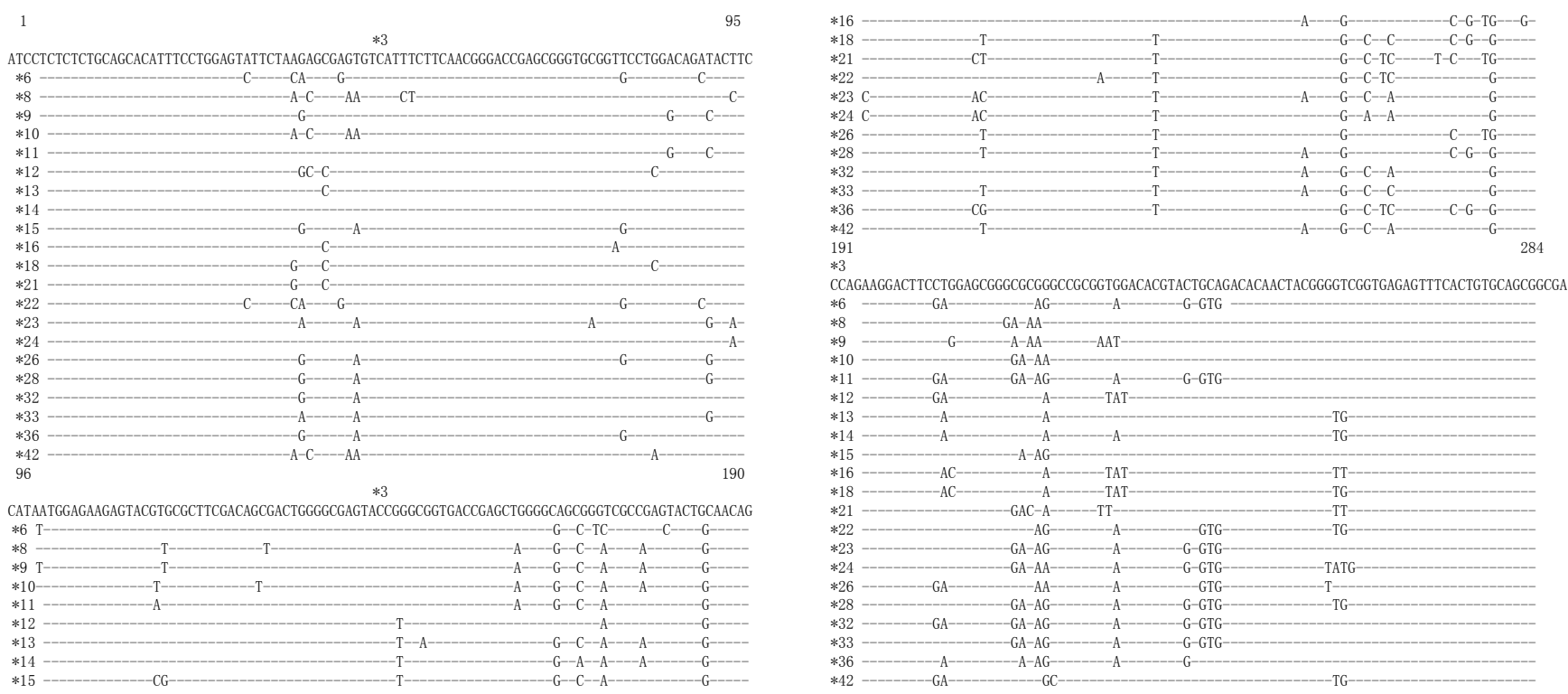

Table 4. The correlation between BoLA-DRB3.2 alleles, lactation, seasons of calving and SCC and performance traits in Chinese Holstein.

\begin{tabular}{|c|c|c|c|}
\hline Factor & $\mathrm{SCC}$ & Factor & $\mathrm{SCC}$ \\
\hline$\mu$ & +580.61 & $\mu$ & +580.61 \\
\hline BoLA-DRB3.2*3 & $-336.95 * *$ & BoLA-DRB3.2*21 & $-503.95^{*}$ \\
\hline BoLA-DRB3. $2 * 6$ & NS & BoLA-DRB3. $2 * 22$ & $-413.38^{*}$ \\
\hline BoLA-DRB $3.2 * 8$ & $-623.01 * *$ & BoLA-DRB3. $2 * 23$ & -345.89 \\
\hline BoLA-DRB3.2*9 & NS & BoLA-DRB3.2*24 & NS \\
\hline BoLA-DRB3.2*10 & NS & BoLA-DRB3. $2 * 26$ & $-878.14 * *$ \\
\hline BoLA-DRB3.2*11 & -341.62 & BoLA-DRB3.2*28 & -386.66 \\
\hline BoLA-DRB3. $2 * 12$ & NS & BoLA-DRB3.2*32 & NS \\
\hline BoLA-DRB3.2*13 & NS & BoLA-DRB3.2*33 & NS \\
\hline BoLA-DRB3.2*14 & NS & BoLA-DRB3.2*36 & -395.54 \\
\hline BoLA-DRB3.2*15 & NS & BoLA-DRB3.2*42 & NS \\
\hline BoLA-DRB3.2*16 & -353.07 & Lactation & $+195.19 * *$ \\
\hline BoLA-DRB3.2*18 & $-511.33 * *$ & Calving Season & $+49.91 * *$ \\
\hline
\end{tabular}

Note:*means significant difference, $\mathrm{P}<0.05 ; * *$ means significant difference, $\mathrm{P}<0.01$; NS means no significant difference. The values means regression coefficient, + means positive correlation, -means negative correlation.

\subsection{Effect of BoLA-DRB3.2, Lactation and Caving Season on SCC}

The effect of BoLA-DRB3.2, lactation and caving season on SCC and production performance are displayed in Table 4 Lactation and calving season have positive correlation with SCC $(\mathrm{p}<0.01)$, most alleles of BoLADRB3.2 have negative correlation with SCC, among them, BoLA-DRB3.2*3, *8, $* 18$ and $* 26$ are the most associated with $\operatorname{SCC}(\mathrm{p}<0.01)$.

\section{DISCUSSION}

Taking an important role in the immune system of animals and having a close relationship with resistance to diseases, MHC has become a candidate gene and a hot point of recent researches. It is widely said that the high polymorphism of MHC-DRB3 genes was decided by its important function made by class II antigen of $\mathrm{MHC}$ in the immune system. In order to adapt to various geographic and climatic conditions, the immune system is highly polymorphic. So the polymorphism of BoLADRB3 gene, encoding the main functional area of MHC antigen, is very high.

Miretti et al. [9] identified the polymorphism of BoLA-DRB3 gene in Argentinean Holstain using PCRRFLP. Four patterns a, b, d and e were found with Hae III, three ( $a, b$ and d) and eleven patterns (b, c, d, f, g, h, $\mathrm{I}, \mathrm{j}, \mathrm{l}, \mathrm{m}, \mathrm{n}$ and o) were found with Bst YI and RsaI, respectively. In this research, Hae III $\mathrm{f}, \mathrm{h}$ and BstYI d were detected. 
The most frequent (frequency $>0.05$ ) BoLA-DRB3.2 alleles of 835 Holstein dairy cattle re-ported by Sharif $e t$ al. [11] were BoLA-DRB3.2*3(0.0652), *8(0.0079), $* 11(0.0874), * 16(0.0048), * 22(0.2353), * 23(0.1017)$, $* 24(0.0922)$. In the present study, the most frequent alleles were BoLA-DRB3.2*3(0.0652), **11(0.0874), *16(0.0048), *22(0.2353), *23(0.1017), *24(0.0922). Sharif et al reported that BoLA-DRB3.2*8 was the most common allele type in Holstein, However, in this study, the BoLA-DRB3. $2 * 16$ was at low frequency $(0.0048)$, while the BoLA-DRB3 $* 22$ was the most common allele (0.2353). Therefore, BoLA polymorphism information from the research herd seemed representative of the regional Holstein population. These differences may be largely due to the long-term adaptation to different geographical and climatic conditions. Therefore, BoLA polymorphism information from the research herd seemed representative of the regional Holstein population. These differences may be largely due to the longterm conditions.

Many mutants, changing the restriction site and the restriction maps, were identified in the cut sites by DNA sequencing. RFLP, as a method to identify the polymorphism of BoLA-DRB3, can only define the position of mutants. Other methods must be used to find the detail mutants. Result of our study demonstrated that the BoLA-DRB3.2 locus is highly polymorphic in Chinese Holstein. PCR-RFLP may therefore be a rapid and useful method for DRB3 typing and studying the evolutionary changes in dairy cattle.

Sharif reported calving season had no significant effect on SCC, but this research indicated that calving season significantly affect SCC; there was a trend that cows calving in spring and summer have high SCC. Related to BoLA-DRB3.2 and SCC, the result in this research is different from Sharif et al. [11], among the most frequently detected alleles, BoLA-DRB3.2*3 has significant correlation to low SCC, BoLA-DRB3. $2 * 8,18$ and 26 maybe have same function, but their frequencies are very low.

Contradictory results from different studies investtigating associations between BoLA-DRB3.2 alleles and mastitis indicate that future studies should focus on associations of mastitis with BoLA heliotypes rather than with single BoLA genes.

\section{ACKNOWLEDGEMENTS}

This The authors appreciate the assistance of the Shanghai Brightlight Dairy Company. This work was supported by 863 high-tech projects "The Breeding technology of Multi-locus Combination of Chinese Holstein" (2008AA10Z144), Natural Science Foundation of Jiangsu Province, College of major projects (09KJA230002), land $863 \mathrm{Na}$ tional key project (2008AA101010).

\section{REFERENCES}

[1] Andersson, L. and Davies, C.J. (1994) The major histocompatibility complex. Cell-Mediated Immunity in Ruminants, CRC, 37-57.

[2] Davies, C.J., Joosten, I., Andersson, L., Arriens, M.A., Bernoco, D., Bissumbhar, B., Byrns, G., van Eijk, M.J., Kristensen, B. and Lewin, H.A. (1994) Polymorphism of Bovine MHC Class II genes. Joint Report of the Fifth International Bovine Lymphocyte Antigen (BoLA) Workshop. European Journal of Immunogenetics, 21(4), 259-289.

[3] Van Eijk, M.J., Stewart-Haynes, J.A. and Lewin, H.A. (1992) Extensive polymorphism of the BoLA-DRB3 gene distinguished by PCR-RFLP. Animal Genetics, 23, 483-496.

[4] Do Nascimento, C.S., Machado, M.A., Martinez, M.L., da Silva, M.G.B., Martins Guimares, M.F., Campos, A.L., Sousa Azevedo, A.L., Teodoro, R.L., Silva erneque, R. and Facioni Guimare, S.E. (2006) Association of the Bovine major histocompatibility complex (BoLA) BoLA-DRB3 gene with fat and protein production and somatic cell score in Brazilian gyr dairy cattle (Bos indicus). Genetics \& Molecular Biology, 29(4), 641-647.

[5] Nassiry, M.R., Shahroodi, F.E., Mosafer, J.A., Mohammadi, A., Manshad, E., Ghazanfari, S., Mohammad Abadi, M.R. and Sulimova, G.E. (2005) Analysis and frequency of Bovine lymphocyte antigen (BoLA-DRB3) alleles in Iranian Holstein cattle. Russian Journal of Genetics, 41(6), 664-668.

[6] Rupp, R., Hernandez, A., Mallard, B.A. (2007) Association of Bovine leukocyte antigen (BoLA) DRB3.2 with immune response, mastitis, and production and type traitsin Canadian Holsteins. Journal of Dairy Science, 90, 1029-1038.

[7] Duangjinda, M., Buayai, D., Pattarajinda, V., Phasuk, Y., Katawatin, S., Vongpralub T. and Chaiyotvittayakul, A. (2009) Detection of Bovine leukocyte antigen DRB3 alleles as Candidate markers for clinical mastitis resistance in Holstein x zebu. Journal of Animal Science, 87, 469-476.

[8] Jeseph, S. and Rusell, D.W. (2001) Molecular cloning: A laboratory manual. Cold Spring Habor Laboratory Press.

[9] Miretti, M.M., Ferro, J.A., Lara, M.A. and Conte, E.P.B. (2001) Restriction fragment length polymorphism (RFLP) in Exon 2 of the BoLA-DRB3 gene in South American cattle. Bio Gene, 39(9-10), 311-324.

[10] Maillard, J., Renard, C., Chardon, P., Chantal, I. and Bensaid, A. (1999) Characterization of 18 new BoLA-DRB3 alleles. Animal Genetics, 30, 200-203.

[11] Sharif, S., Mallard, B.A., Wilkie, B.N., Sargeant, J.M., Scott, H.M., Dekkers, J.C.M. and Leslie, K.E. (1998) Association of the Bovine major histocompatibility complex DRB3 (BoLA-DRB3) alleles with occurrence of disease and milk somatic cell score in Canadian dairy cattle. Animal Genetics, 29, 185-193. 